http://jurnalstttenggarong.ac.id/index.php/JTP

Sekolah Tinggi Teologi Tenggarong

p-ISSN 2722-8916, e-ISSN 2722-8908

Edisi: Volume 2, Nomor 1, Juni 2021

halaman: $67-77$

\title{
Kajian Teologis Tentang Gaya Hidup "Hedonisme" dalam Amsal 21:17 dan Yesaya 5:11 Serta Implikasinya Bagi Orang Kristen Masa Kini
}

\author{
Yosep Iswanto Padabang \\ STT Arastamar Wamena \\ Email: yosepiswanto3@gmail.com \\ Iwan Bambang \\ Sekolah Tinggi Teologi Tenggarong \\ Email: dr.iwandanrose@gmail.com
}

\begin{abstract}
:
Looking for everything that is in accordance with the wishes and pleasing to the human heart (Hedonism) is something that is commonplace and is always attached to everyone, but in doing it humans need to be guided and controlled by a basis, which makes humans always supervised so they don't fall into their own desires and ultimately self-destruct. As in Christianity, human desires should be in accordance with God's wishes, and everything that pleases the human heart must also please God and glorify God. Then what about Christians today, are they still walking according to God's wishes or their own desires? The author uses descriptive qualitative methods, while related to theological studies in relation to the hedonistic lifestyle, the authors relate descriptive qualitative research in the context of phenomenology with qualitative methods that are library research. Which is to analyze the content of meaning contained in a narrative or text, in relation to the Scriptures, the author uses narrative analysis. And in the and it can be concluded that the Christian life should be under the life of love and continue to walk under the grace and covenant of God, so that Christians can avoid a lifestyle that only seeks worldly pleasures that are limited and ultimately lead to destruction.
\end{abstract}

Key Words: Lifestyle, Hedonism, Christians.

\begin{abstract}
Abstrak:
Mencari segala sesuatu yang sesuai dengan keinginan dan menyenangkan hati manusia (Hedonisme) adalah sesuatu yang lumrah dan selalu melekat pada diri setiap orang, namun dalam menjalaninya manusia perlu digiring dan dikontrol oleh sebuah dasar, yang menjadikan manusia selalu diawasi sehingga tidak terjerumus dalam keinginannya sendiri dan pada akhirnya membuat dirinya sendiri binasa. Sebagaimana dalam pandangan Kekristenan keinginan manusia sebaiknya sesuai dengan keinginan Tuhan, dan segala sesuatu yang menyenangkan hati manusia tentu juga menyenagkan hati Tuhan dan memulikan Tuhan. Lalu bagaimana dengan orang Kristen saat ini, apakah masih berjalan sesuai dengan keinginan Tuhan atau keinginan dirinya sendiri? Penulis menggunakan metode kualitatif deskriptif, sedangkan terkait dengan kajian teologi dalam kaitannya dengan gaya hidup hedonisme, penulis mengaitkan penelitian yang bersifat kualitatif deskriptif dalam konteks fenomenologi dengan metode kualitatif yang bersifat library research. Yang mana untuk menganalisis kandungan makna yang terdapat dalam sebuah narasi atau teks, dalam kaitannya dengan Kitab Suci, penulis menggunakan analisis naratif. Dan pada akhirnya dapat disimpulkan bahwa Kehidupan orang Kristen sebaiknya dibawah dalam kehidupan kasih dan terus berjalan di bawah anugerah dan perjanjian Allah, sehingga orang krisen dapat terhindar dari gaya hidup yang hanya mencari kesenangan dunia yang terbatas adanya dan pada akhirnya membawa kebinasaan.
\end{abstract}

Kata Kunci: Gaya Hidup, Hedonisme, Orang Kisten.

Article History

Submit:

Revised:

Published:

June $28^{\text {th }}, 2021$

June $30^{\text {th }}, 2021$

June $30^{\text {th }}, 2021$ 


\section{Pendahuluan}

Manusia selalu menjadi subjek dan objek terhadap segala perkembangan ilmu pengetahuan. Dalam perkembangannya, kehidupan manusia tidak dapat dipisahkan dengan suatu Gaya Hidup yang melekat pada manusia itu sendiri. pertanyaan tentang gaya Hidup pada manusia, akan dijawab dengan berbagai sudut pandang sesuai dengan konteks atau keadaan dimana gaya hidup itu dibicarakan. Berkaitan dengan hal ini, seperti yang dikemukakan oleh Garlans ( 2009) bahwa gaya hidup merupakan, suatu bentuk dari saling interaksi antara manusia sehinga memicu suatu pola dalam kehidupan. Gaya hidup sebagai sesuatu kegiatan dalam kehidupan manusia, yang terus berkalanjutan tergantung dari kontesk interaksi manusia itu sendiri, pada tempat dimana manusia berada. Tentu bahwa yang dimaksud dengan interaksi disini dalam kaitannya dengan gaya hidup adalah sebuah reaksi dalam diri manusia untuk terus ingin melakukan sesuatu yang berkaitan dengan keberlangsungan hidupnya.

Dalam memahami gaya hidup itu sendiri tentu tidak dapat dipisahkan dengan konteks atau waktu dimana manusia itu berada. Berkaitan dengan konteks atau waktu, saat ini keberadaan manusia atau gaya hidup manusia berada pada satu fase yang terus dipengaruhi oleh Ilmu Pengetahuan dan Teknologi (IPTEK) yang berkembang begitu cepat dan selalu memberikan dorongan atau perspektif tersendiri baik, yang bersifat positif maupun yang bersifat negatif. Berkaitan dengan hal ini seperti yang dikemukakan oleh Suryanti (2010) mengatakan bahwa perkembangan IPTEK dan perubahan gaya hidup dikalangan kaum muda berpengaruh terhadap cara pandang dan sikap kaum muda terhadap agama.

Berdasarkan apa yang dikemukakan oleh Suryani pada paragraf sebelumnya penulis memahami bahwa, cara pandang seseorang sangat mempengaruhi gaya hidup seperti apa yang nantinya akan hendak ia jalani. Dalam kaitannya dengan perkembangan Ilmu Pengetahuan dan Teknologi (IPTEK) saat ini fakta memperlihatkan bahwa ada banyak perubahan gaya hidup dari manusia yang terus berubah zaman ke zaman. Tentu bahwa, saat ini manusia hidup dalam sebuah gaya hidup yang terus dimanjakan dengan segala sesuatu yang serba instan. Masih terkait dengan gaya hidup itu sendiri, Juolanda (2013) juga mengemukakan bahwa pada zaman modern saat ini banyak hal dunia yang ditawarkan agar manusia bisa mencapai tingkat kepuasannya untuk bahagia. Masih terkait dengan gaya hidup Maslow juga menegaskan bahwa di dalam diri manusia selalu ada suatu usaha yang positif untuk berkembang dan manusia juga memiliki kekuatan untuk menolak berkembang, Maslow juga mengemukakan bahwa individu berprilaku dalam upaya untuk memenuhi kebutuhan yang bersifat hierarkis.(Zikrun, 2018, p. 72) melihat apa yang dikemukana oleh kedua tokoh diatas penulis memahami, dalam kaitannya dengan gaya hidup, selalu didorong oleh kepribadian dari manusia itu sendiri, namun tidak dapat dipisahkan juga dengan keberadaan suatu zaman dimana manusia itu berada.

Berdasarkan dua argumentasi diatas juga penulis memahami bahwa keberadaan Gaya hidup, sangat dipengaruhi oleh Zaman dimana seseorang itu hidup dan berada. Dalam hal ini, tentunya penulis dapat menarik suatu kesimpulan bahwa keberadaan suatu gaya hidup seseorang tidak dapat dipisahkan dengan keberadaan suatu perkembangan Zaman. Berkaitan 
dengan zaman saat ini, mempertegas kembali apa yang dikemukakan oleh Juolanda penulis memahami bahwa ada banyak hal dunia yang ditawarkan kepada manusia dan dalam tanda kutip mungkin ada yang sedikit bertentangan dengan gaya hidup yang diajarkan Allkitab contohnya seperti wanita Zaman sekarang lebih cenderung untuk mempergunakan hartanya untuk membeli dan mempercantik diri dengan berbagai peralatan percantikan yang saat ini berkembang. Contoh lain lagi yaitu saat ini orang lebih cenderung memahami hidup ini adalah untuk memuaskan keinginan dengan segala sesuatu yang dia miliki, yaitu membeli barangbarang yang mahal untuk ditunjukan kepada orang lain.

Hal yang juga tidak kalah penting dalam memahami gaya hidup adalah ketika kita mengaitkannya dengan gaya hidup hedonisme. Sebelum memahami bagian ini, tentu bahwa akan lebih baik, kita terlebih dahulu memahami salah satu dasar pemikiran hedonisme Sebagaimana yang dikemukakan oleh John Stuart Mill dalam jurnalnya Asep Siapulah bahwa sesejahtraan atau kesenangan secara lahir dan batin harus dipunyai oleh masyarakat tidak hanya berlaku untuk individu semata melainkan juga untuk mengetahui kesenjangan sosial di dalamnya.(2020, p. 246)

Dengan demikian maka hedonisme itu sendiri adalah pendangan hidup yang menganggap bahwa orang akan merasa bahagia dengan mencari kebahagiaan sebanyak mungkin dan sedapat mungkin menghindari perasaan-perasaan yang menyakitkan. (Sri, 2018) erdasarkan pernyataan ini, terkait dengan pengertian dari hedonime, penulis memahami bahwa hedonisme adalah pandangan yang mengajarkan orang untuk selalu hidup bahagia dan tidak ingin menikmati kesusahan. Tentu bahwa kebahagian yang dimaksudkan disini, sangat berkaitan erat dengan keseluhuran eksistensi manusia yang juga melipu pemenuhan kebutuhan hidup manusia. Dalam kaitannya dengan pemenuhan kebutuhan dalam hidup, Seperti yang dikemukakan oleh Suryani pada paragraf sebelumnya, penulis memahami bahwa keberadaan suatu gaya hidup hedoniseme seseorang akan menuntut seseorang untuk bertindak dan berusaha untuk memperoleh sesuatau berdasarkan apa yang dia inginkan.

Masih berkitan dengan hedonisme dalam kaitannya dengan pemenuhan kebutuhan hidup seseorang, pada fase abab modern saat ini, muncul suatu gaya hidup hedonisme yang tidak asing untuk ditemukan yaitu, dimana ada kelompok orang tertentu yang selalu ingin hidup enak dan tidak mau hidup dalam kesusahan. Tentu bahwa ini adalah hal yang wajar karena pada dasarnya manusia selalu mau ingin untuk hidup bebas, dan menikmati semua yang dia inginkan. Namun ketika pola kehidupan ini dikaitkan dengan pengajaran kekristenan, tentu akan memberikan pandangan yang sedikit bertentang dan tidak sesuai dengan apa yang diajarkan dalam Alkitab. Sebab dalam kekristenan selalu mengajarkan untuk hidup harus memikul salib, atau hidup hidup kembali kepada maksud dan keinginana Tuhan.

Melihat dua perbedaan pandangan dalam penerapan gaya hidup hedonisme dan pandangan gaya hidup dalam kekristenan ini. Maka tentunya akan menimbulkan pertanyaan dalam kajian ini, bagaimana dengan kehidupan kekristenan atau orang percaya saat ini? Apakah orang Kristen saat ini terjerumus dalam gaya hidup hedonisme? Tujuan dari kajian ini untuk 
memberikan pemahaman melalui pengajaran yang didasarkan pada Alkitab sebagai dasar atau acuan yang mutlak agar orang Kristen dapat terhindar dari gaya Hidup Hedonisme.

\section{Metode Penelitian}

Penelitian ini menggunakan pendekatan kualitatif dengan metode kajian pustaka sebagaimana yang dikemukakan oleh Rawambaku (2015) yaitu, masalah yang telah dirumuskan harus segera diikuti dengan upaya mencari teori dan konsep, dan generalisasi yang dapat dijadikan landasan teoritis bagi penelitian yang akan dilakukan. Yang mana adapun masalah yang perlu dikaji saat ini yaitu banyak kehidupan orang percaya yang telah terjerumus dalam gaya hidup hedonisme. Terkait dengan kajian teologi dalam kaitannya dengan gaya hidup hedonisme, penulis mengaitkan penelitian yang bersifat kualitatif deskriptif yang bersifat library research. Creswell (2016) mengemukakan bahwa kualitatif research dilakukan untuk menganalisis kandungan makna yang terdapat dalam sebuah narasi atau teks, dalam kaitannya dengan Kitab Suci, penulis menggunakan analisis naratif. Gertz, Berlejung, Schmid, \& Witte, (2017) mengemukakan kandungan makna yang terdapat pada beberapa kata melalui penelusuran terhadap Alkitab. Untuk mengetahui ayat Alkitab dalam Perjanjian Lama yang berbicara tentang gaya hidup hedonism. Dengan demikina maka dalam artikel ini penulis menggunakan metode kualitatif deskriptif, yang didalam juga penulis dipadukan dengan pendekatan library research dengan upaya analisa secara teoretis.

\section{Hasil dan Pembahasan}

\section{Gaya Hidup}

Keberadaan manusia pada suatu tempat tidak dapat dipisahkan dengan gaya hidup seperti apa yang ia gunakan dalam menjalani hidup nya. Dengan demikian berarti ketika memahami gaya hidup, maka sebetulnya kita sendang memahami manusia itu sendiri, dalam konteks apa yang sedang dan akan dia buat. Tentu bahwa untuk memahami bagian ini lebih jauh dan mendalam maka kita perlu mengetahui apa sebertulnya gaya hidup itu. Menurut Gerlans (Tambingon et al., 2016) bahwa gaya hidup merupakan suatu bentuk dari interaksi antara manusia sehingga memicu suatu pola dalam kehidupan. Gaya hidup idak dapat dipisahkan dengan suatu interaksi yang terjadi pada manusia yang kemudian membentuk suatu pola kehidupan yang hendak akan dijalani. Interaksi yang dimaksudkan merujuk pada apa yang manusia itu sendiri kerjakan untuk mendapatkan sesuatu, dan juga seperti apa manusia tersebut mempergunakan segala harta dan miliknya untuk memenuhi segala keinginannya. Tentu juga bahwa, dalam semua kegiatan ini tidak dapat dipisahkan dengan pola atau cara seperti apa yang manusia itu gunakan. Baik itu cara yang bersifat negatif, maupun cara yang bersifat positif, yang tentunya diharapkan dapat membawa hasil bagi diri manusia itu sendiri, atau mungkin juga bagi orang lain sesuai dengan kehendaknya.

Masih barkaitan dengan gaya hidup, Kasali (2008) juga mengemukakan bahwa gaya hidup pada prinsipnya adalah bagaimana seseorang menghabiskan waktu dan uangnya. Yupriel 
yang dikutip Tambingon et al., (2016) menyatakan bahwa gaya hidup diartikan sebagai pola tingka laku sehari-hari segolongan manusia dalam masyarakat. Gaya hidup terkait dengan bagaimana seseorang menghabiskan segala harta miliknya, untuk memenuhi segala keinginananya, yang tentunya terjadi dalam suatu kurun waktu tertentu.

\section{Gaya Hidup Hedonisme}

Untuk memahami lebih jauh apa sebetulnya gaya hidup hedonisme, maka alangkah lebih baik penulis memulainya dengan apa itu hedonisme, yang tentunya menjadi pokok utama pada bagian ini, dan kemudian akan dihubungkan dengan gaya hidup itu sendiri. Berkaitan dengan Hedonisme, Bertens (2004) mengemukakan bahwa hedonisme pertama kali dikemukakan oleh seorang filsuf dari Yunani yang bernama Aristippos tahun 433-335 SM, yang mengatakan bahwa hal terbaik bagi manusia adalah kesenangan, Aristippos juga menekankan bahwa Kesenganan disini harus dimengerti sebagai kesenagan yang aktual. Masih terkait dengan pengertian hedonism, Kartono (1997) mengatakan bahwa Hedonis yang berasal dari kata hedonisme memiliki arti pandangan hidup yang menganggap bahwa kesenangan dan kenikmatan materi adalah tujuan utama dari hidup manusia.

Hedonisme sebagai pandangan hidup yang menganggap kesenangan dunia adalah tujuan utama atau hal terbaik dari hidup manusia. Menurut Susanto yang dikutip Azizah \& Indrawati (2015) bahwa gaya hidup hedonisme merupakan pola hidup atau interkasi seseorang dengan lingkungannya yang hanya berorientasi pada kesenangan atau kenikmatan dalam kegiatan, minat, dan pendapat. Gaya hidup hedonisme sebagai suatu kegiatan yang berkaitan erat dengan Pola hidup dan interkasi manusia setiap hari yang berhubungan dengan segala sesuatu yang mendatangkan kesenangan dan kenikmatan bagi kehidupannya. Pola hidup dan interkasi dalam konteks ini meliputi, cara untuk memperoleh sesuatu, cara untuk mempergunakan segala sesuatu, yang meliputi interkasi setiap hari untuk memenuhi segala keinginananya.

Masih terkait dengan pengertian dari gaya hidup hedonisme itu sendiri, menurut Amstrong (Trimartati, 2014) mengatakan bahwa gaya hidup hedonisme adalah suatu pola hidup yang aktifitasnya untuk mencari kesenangan hidup, seperti lebih banyak menghabiskan waktu diluar rumah, lebih banyak bermain, senang pada keramaian kota, senang membeli barang mahal yang disenanginya, serta selalu ingin menjadi pusat perhatian. Gaya hidup hedonisme sebagai suatu pola hidup yang hanya mencari kesenagang dan kenikmatan yang dapat terlihat dalam aktifitas sehari - hari seperti membeli barang-barang mahal untuk kesenagan diri sendiri, selalu mau ingin menghabiskan waktu dan uang untuk jalan - jalan ke tempat ramai seperti Mall dan tempat - tempat wisata lainnya. Gaya hidup hedonisme sebagai suatu pola hidup yang dalam aktualisasinya, selalu mengedepankan kesenangan dan kenikmatan yang terlihat dalam aktifitas sehari - hari seperti: menghabiskan uang untuk membeli barang-barang mahal sesuai keinginan hati, menghabiskan waktu untuk pergi ke tempat - tempat ramai dan menyenangkan contohnya Mall, tempat Wisata dan tempat - tempat ramai lainnya sesuai dengan keinginan nya. 


\section{Nats Amsal 21:17}

Untuk memahami bagaimana hedonisme dalam ayat ini lebih jauh maka penulis akan merumuskan beberapa terjemahan yang sering digunakan dalam mengemukanan makna yang baik dan tepat dalam memahami sebuah teks dalam Alkitab, berikut ini adalah beberapa terjemahan yang akan penulis gunakan menjadi dasar dalam memahami Hedonisme dalam Amsal 21:17 yaitu: "Orang yang suka bersenang-senang akan berkekurangan, orang yang gemar kepada minyak dan anggur tidak akan menjadi kaya." Kata bersenang-senang dalam teks ini merupakan terjemahan dari kata dalam Bahasa Ibrani, yaitu שְְִׁ (simchah) yang berarti:

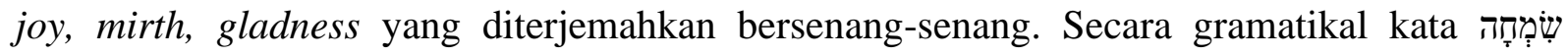
(simchah) berbentuk noun accusative masculine singular. Bersenang-senang dalam konteks ini menunjuk pada keadaan yang menggembarkan emosi dan ditampilkan dalam perilaku dimana dirinya menunjukkan Tindakan suka bersenang-senang.(BibleWorks, 2018) Kata ini juga menunjuk suatu tindakan hanya untuk pemuasan kesenangan yang dilakulan terus menerus tanpa batas. Sedangkan kata berkekurangan merupakan terjemahan dari kata מְּ (machcowr) yang diartikan a need, thing needed, poverty. Artinya menjadi berkekurangan dari apa yang dibutuhkan atau dalam terjemahan lain diartikan menjadi miskin. Secara gramatikal kata (machcowr) berbentuk noun common masculine singular, (BibleWorks, 2018) yang berarti bahwa menjadi miskin karena hidup bersenang-senang ditujukan kepada seseorang yang melakukan. Bersenang-senang dengan hidup berfoya-foya sebagai gaya hidup, akan menjadikan seseorang mengalami kekurangan dari apa yang semestinya dibutuhkan atau akan menjadi miskin secara substansial. Sedangkan "gemar kepada minyak dan anggur" dalam terjemahan Alkitab Bahasa sehari-hari diartikan suka berfoya-foya.

Guthrie et al. (2008) memberikan penjelasan bahwa pada bagian ayat ini, terdapat tiga hal penting, yaitu: Pertama, menunjuk kepada seorang raja yang mungkin kelihatan sangat berkuasa tapi hatinya dikendalikan Allah dengan Ketat, seperti penjaga pintu air menutup dan membuka dan mengawasi air dalam sungai (bnd 16:2) Kedua, pelita maksudnya: mungkin kaidah-kaidah yang dipakai orang jahat, mungkin juga lambang kejayaan mereka (bnd 13:9). Ketiga mencari maut, walaupun padat artinya cukup terang. Gaya hidup hedonisme yang dibicarakan dalam Kitab Amsal 21:17 adalah orang yang berkusa yang kemudian mempergunakan segala kekuasaan dan hartanya untuk memuaskan keinginannya. Pada sisi yang lain penulis juga mengerti bahwa orang yang berkuasa diatas yang dibicarakan adalah orang yang jahat yang kemudian akhir dari hidupnya adalah menuju kepada alam maut. Menurut Guthrie et al., (2008) adalah: kelompok orang yang berkuasa atau orang yang memiliki harta yang banyak kemudian mempergunakan kekuasaannya dan harta untuk memenuhi keinginannya yang kemudian akan binasa dengan dunia ini. 


\section{Nats Yesaya 5:11}

Masih mengunakan pola yang sama dalam melihat maksud dari ayat ini, untuk menemukan apa yang dibicarakan dalam bagian ini terkait dengan hedonisme dalam Yesaya 5:11 yang menyatakan "Celakalah mereka yang bangun pagi-pagi dan terus mencari minuman keras, dan duduk-duduk sampai malam hari, sedang badannya dihangatkan anggur!”. Kata dan Frasa dalam nast ini yaitu, pertama, yaitu "mereka yang bangun pagi-pagi dan terus mencari minuman keras" dan kata atau frasa kedua, yaitu "duduk-duduk sampai malam hari sedang badannya dihangatkan dengan anggur". Melihat dua frasa dalam ayat ini dengan tetap memperhatiakn pengertian harafia dari hedonisme itu sendiri maka ayat ini sedang berbicara tentang salah satu dari perilaku atau pola hidup hedonisme di kalangan umat Perjanjian Lama yang berada pada masa pelayanan nabi Yesaya.

Menurut Guthrie et al., (2008) terkait dengan nats Yesaya 5:21 bahwa terdapat tiga perilaku yang merupakan bagian dari perilaku hedonisme. Pertama, Pemeras-pemeras. Pada bagian ini lebih berkaitan dengan hukum pemilikan yang telah dipertahankan oleh Nabot dengan hidupnya (bnd imamat 25 ayat 23; I Raj 21:3) yaitu lebih berkaitan dengan kegandrungan untuk memiliki tanah-tanah yang kosong akan dipenuhi secara ironis. Kedua Playboy-Playboy, yang pada bagian ini lebih berkaitan dengan cara berpikir menyesatkan (bnd 5:20,21), okultisme (bnd 8:19,20) atau berbentuk kemewahan yang bergemilang yang dilukiskan disini. Kemudian dilanjutkan dengan hukuman atas para sensualis, Sama halnya dengan hukuman bagi perempuan-perempuan yang gila pakaian. Di dalam pasal 3:16 berbicara tentang kehilangan hal-hal yang mereka cari dan himpun, dan yang ke tiga adalah pengejekpengejek. Karena dalam Bahasa Ibrani sering satu perkataan yang sama dipakai untuk suatu benda dan hasilnya, ayat 18 dapat berarti yang memancing hukuman (atas diri mereka sendiri) yang memancing pembalasan. Tetapi mungkin kiasan ini berbunyi sedikit asing karena para pengejek dalam kesesatannya bukanlah tersesat dalam dosa tapi malah karena asik dengannya. Hedonisme yang dibicarakan dalam ayat ini, yaitu: Pertama orang yang ikut memeras bagiannya orang lain dan menikmatinya sendiri dengan menggunakan strategi kekuasaan yang dimilikinya. Kedua, orang yang selalu berfoya-foya. Dalam hal ini menghabiskan uang dengan membeli berbagai perhiasan dan merasa puas dengannya. Ketiga, orang yang selalu memandang rendah orang lain dan selalu merasa tidak takut dengan Tuhan.

Menurut Oswalt (1986) bahwa ketika seseorang dikuasai oleh keinginan hanya untuk pemenuhan kesenangan sebagai gaya hidup, maka gairah untuk Tuhan dan hidup dalam kebenarannya akan hilang. Justru ketika seseorang dikuasi keinginan yang menjadikan alcohol sebagai kesenangan, maka dirinya justru menjadi tidak peka terhadap tanggungjawab dan nilainilai. Artinya gaya hidup hedonism jutsru menjadikan seseorang akan kehilangan arah hidup, hidup terpisah dari Tuhan dan kehilangan tanggungjawab dalam segala aspek kehidupan. 


\section{Implikasi Bagi Orang Kristen Masa Kini}

Terdapat tiga bagian dari gaya hidup hedonisme yang tentunya menjadi poin penting dalam bagian ini berkaitan dengan implikasi dalam penulisan ini bagi orang Kristen, yaitu:

\section{Orang Kristen hidup untuk menyenangkan hati Tuhan}

Menjadi salah satu hal penting yang selalu ada dalam pandangan hidup kelompok hedonisme yaitu hidup mencari dan merasakan kesenangan dan kenikmatatan diri sendiri. Maka pada bagian ini, penulis hendak menguraikan Tujuan hidup orang Kristen adalah untuk memenuhi keinginan Tuhan. Berkaitan dengan hal ini seperti yang dikemukakan oleh Verkuyl (2016) mengatakan bahwa tujuan hidup manusia terletak pada kerajaan Allah, yang mana Kerajaan Allah itu telah datang di dalam Yesus Kristus. Tujuan hidup orang Kristen seharusnya adalah untuk mencari dan mengenal maksud Tuhan melalui Anaknya Yesus Kristus yang telah datang dan membawa Kerajaan Allah itu kedalam dunia dimana manusia itu hidup. Orang Kristen hanya hidup untuk memcari hal - hal yang menyenangkan hatinya, maka dia akan binasa dengan dunia ini, yang menjadi tempat dimana dia menikmati semua keinginannya. Seperti yang tercatat dalam Amsal 21:17 dan Yesaya 5:11. Tentu bahwa menjadi manusia yang hidup menyenangkan hati Tuhan adalah sesuatu yang sulit namum, Prinsip iman Kristen selalu mengajarkan bahwa Tuhan Yesus telah mengajarkan semua itu kepada kita, sehingga tidak ada keraguan untuk mau melangkah dan menjadikan hidup ini selalu menyenagkan hati Tuhan, bukan untuk menyenagkan diri sendiri.

Masih berkaitan dengan manusia hidup untuk menyenagkan hati Tuhan, Napel (2012) juga mengatakan bahwa sebetulnya orang Kristen jangan hidup mengasihi dunia ini, karena sengguhnya kita diutus untuk mengerjakan kerajaan yang Allah telah kerjakan melalui anaknya Yesus Kristus. Tujuan hidup manusia hanya untuk menyenangkan hati Tuhan dan melanjutkan kerajaan-Nya, yang telah Allah kerjakan melalu Anaknya Yesus Kristus, dan mehindari gaya hidup yang hanya mengutamakan Kesenangan dan kenikmatan dunia sendiri seperti yang dilakukan oleh kelompok hedonisme. Dengan demikian, yang dimaksudkan dengan manusia hidup menyenangkan hati Tuhan adalah hidup yang selalu mengutamakan dan mengerjakan pekerjaan yang bersifat membangun Kerajaan Allah, seperti yang telah dikerjakan oleh Yesus Kristus, sebagai bagian mutlak dari tujuan hidup Orang Kristen di dunia ini.

\section{Kesenagan dunia hanya terbatas dan sementara}

Merujuk pada bagian yang telah dibahas pada poin sebelumnya terkait dengan gaya hidup hedonism, baik secara teoritis, maupun yang terkait dengan Amsal 21:17 dan Yesaya 5:11, maka, kesenangan dunia hanya terbatas dan sementara. Orang-orang yang mencitai dunia yang nantinya akan binasa dengan dunia ini, seperti yang ditegaskan pada penjelasan Nats Amsal 21:17. Penekanan pada poin ini tentunya sangat bertentang dengan gaya hidup hedonisme. Yang mana salah satu perilaku dari kelompok hedonisme adalah terus mau mencari dan menikmati segala sesuatu yang berada dalam dunia ini, untuk memenuhi keinginanya. 
Orang-orang yang mencintai dunia dan terus mencari kesenangan dunia akan menjadi binasa dengan dunia ini.

Dengan demikian maka, apa implikasi yang harus dilakukan oleh orang Kristen atau bagaimana orang Kristen memaknai bagian ini agar tidak dapat terhindar dari kesenangan dunia yang hanya terbatas, dan dapat membinasakan ini. seperti yang dikemukakan oleh Stassen \& Gushee (2008) bahwa orang Kristen harus hidup dalam kasih dan keadilan. Tentu bahwa memahami kasih saja tidak cukup sehingga orang Kristen juga harus hidup dalam kehidupan Doa dan permenungan Firman Tuhan yang terjadi setiap waktu dan selalu diaplikasikan dalam kehidupan setiap hari.

Masih terkait dengan topik pada bagian ini yaitu kesengan dunia yang hanya terbatas dan sementara, maka orang Kristen juga harus selalu hidup dalam pemerintahan Allah, seperti yang dikemukakan oleh Sosipater (2010) bahwa orang percaya harus selalu hidup di bawah anugerah dan perjanjian Allah sebagaimana Tuhan sendiri berjanji akan memberikan kehidupan yang kekal bagi orang yang selalu hidup mengasihi dia dalam perkataan dan perbuatannya. Dengan demikian maka ketika orang Kristen memahami bahwa kehidupan kekritanan harus dibawah dalam kehidupan kasih dan terus berjalan di bawah anugerah dan perjanjian Allah, sehingga orang krisen dapat terhindar dari gaya hidup yang hanya mencari kesenangan dunia yang terbatas adanya.

\section{Pergunakan waktu dan uang untuk memuliakan Tuhan}

Merujuk pada salah satu gaya hidup hedonisme seperti yang dikemukakan oleh R. Kasali (2011) dan uraian dari teks Amsal 21:17 dan Yesaya 5:11, yang mana menjelaskan salah satu gaya hidup hedonisem yaitu selalu menghabiskan uang dan waktu untuk hal-hal yang menyenangkan dan membawa kenikmamatan bagi dirinya sendiri. Maka dalam kaitannya dengan pergunakan waktu dan uang untuk memuliakan Tuhan, penulis menyadari bahwa perilaku hedonisem ini sangat bertentangan dengan pengajaran kekritenan yang sesunguhnya. yang mana Alkitab selalu mengajarkan bahwa segala sesuatu yang ada pada manusia harus dipersembahkan untuk Tuhan, sebagaimana Allah menciptakian manusia untuk mencapai rencana dan maksudnya, sebagaimana Allah yang "aktif kreatif” dan "dinamis" dalam bekerja maka manusia juga diharapkan memiliki sikap yang sama sebagaimana seperti Gambar dan rupah Allah itu sendiri.

Masih berkaitan dengan pergunakan waktu dan uang untuk memuliakan Tuhan, orang Kristen perlu menyadari bahwa segala sesuatu yang saat ini dimilikinya adalah dari Tuhan dan semuanya akan kembali kepada Tuhan. Namun bagaimana orang Kristen menyadarinya dan melakukannya dengan baik, sebagaimana yang dikemukana oleh Sosipater (2013) bahwa manusia harus selalu menjaga Citra Allah yaitu Gambar dan Rupa Allah yang selalu terwujud dalam sikap dan tindakan. Mengacu pada apa yang dikemukan oleh Karel diatas maka penulis dapat menyimpulkan bahwa ketika orang Kristen menyadari bahwa dirinya merupakan segambar dan serupa dengan Allah maka sebaiknya diwujudkan dalam perilaku dan tindakannya seperti yang Allah harapkan bagi dirinya, sebagaimana berkaitan dengan poin pada 
bagian ini bahwa dalam mempergunakan uang dan waktu yang ada harus selalu sesuai dengan keinginan dan memulikan Tuhan, sebagaimana yang Tuhan inginkan yaitu menjadi segambar dan serupa dengan Allah dalam sikap dan tindakan

\section{Kesimpulan}

Mencari segala sesuatu yang sesuai dengan keinginan dan menyenangkan hati manusia adalah sesuatu yang lumrah dan selalu melekat pada diri setiap orang, namun dalam menjalaninya manusia perlu digiring dan dikontrol oleh sebuah dasar, yang menjadikan manusia selalu diawasi sehingga tidak terjerumus dalam keinginan nya sendiri dan pada akhirnya membuat dirinya sendiri binasa. Sebagaimana yang diuraikan pada tulisan ini bahwa keinginan manusia harus sesuai dengan keinginan Tuhan, dan segala sesuatu yang menyenangkan hati manusia tentu juga menyenagkan hati Tuhan dan memulikan Tuhan.

Akibat dari kehidupan manusia yang tidak digiring dan diawasi Tuhan, maka akan terbawa dengan sautu gaya hidup baru, gaya hidup hedonisme, yang mana tidak sesuai dengan keinginan Tuhan. berkaitan dengan hal ini, sebagaimana yang menjadi persoalan yang dibahas dalam penulisan ini, maka penulis dapat memberikan beberapa kesimpulan sebagai berikut:

Pertama: Gaya hidup adalah segala tingka laku manusia dalam kehidupan sehari-hari yang tergolong juga dalam bagaimana tidakan manusia menghabiskan segala waktu dan uangnya dengan menggunakan pola tertentu untuk mencapai segala keinginannya.

Kedua: Gaya hidup hedonisme adalah suatu pola hidup yang dalam aktualisasinya, selalu mengedepankan kesenangan dan kenikmatan yang terlihat dalam aktifitas sehari - hari seperti: menghabiskan uang untuk membeli barang-barang mahal sesuai keinginan hati, menghabiskan waktu untuk pergi ke tempat - tempat ramai dan menyenangkan contohnya Mol, tempat Wisata dan tempat - tempat ramai lainnya sesuai dengan keinginan nya.

Ketiga: Hedonisme dalam perjanjian lama adalah (1) Kelompok orang yang berkuasa atau orang yang memiliki harta yang banyak kemudian mempergunakan kekuasaannya dan harta untuk memenuhi keinginannya yang kemudian akan binasa dengan dunia ini. (2) Hedonisem adalah orang yang selalu berfoya-foya, dalam hal ini menghabiskan uang dengan membeli berbagai perhiasan dan merasa puas dengannya dan yang ketiga hedonisme adalah orang yang selalu memandang rendah orang lain dan selalu merasa tidak takut dengan Tuhan.

Keempat: Implikasinya bagi orang Kristen adalah (1) Orang Kristen harus memiliki hidup yang selalu mengutamakan dan mengerjakan pekerjaan yang bersifat membangun Kerajaan Allah seperti yang telah dikerjakan oleh Yesus Kristus, sebagai bagian mutlak dari tujuan hidup Orang Kristen di dunia ini. (2) Kehidupan kekristenan harus dibawah dalam kehidupan kasih dan terus berjalan di bawah anugerah dan perjanjian Allah, sehinga orang Kristen dapat terhindar dari gaya hidup yang hanya mencari kesenangan dunia yang terbatas adanya. (3) Dalam mempergunakan uang dan waktu yang ada harus selalu sesuai dengan keinginan dan memulikan Tuhan, sebagaimana yang Tuhan inginkan yaitu menjadi segambar dan serupa dengan Allah dalam sikap dan tindakan. 


\section{Daftar Rujukan}

Azizah, F. N., \& Indrawati, E. S. (2015). Kontrol Diri Dan Gaya Hidup Hedonis Pada Mahasiswa Fakultas Ekonomika Dan Bisnis Universitas Diponegoro. Jurnal Empati, 4(4), $156-162$.

Bertens, K. (2004). Etika. Jakarta: Gramedia Pustaka Utama.

BibleWorks. (2018).

Creswell, J. W. (2016). Research Design, Pendekatan Metode Kualitatif, Kuantitatif, dan Campuran. Yogyakarta: Pustaka Pelajar.

Gertz, J. C., Berlejung, A., Schmid, K., \& Witte, M. (2017). Eksplorasi Ke Dalam Kitab-Kitab

Perjanjian Lama Dan Deuterokanonika (1st ed.). Jakarta: BPK Gunung Mulia.

Guthrie, D., Motyer, A., Stibbs, A. M., \& Wiseman, D. J. (2008). Tafsiran Alkitab Masa Kini

2. Jakarta: Yayasan Komunikasi Bina Kasih/OMF.

Hendrik Rawambaku. (2015). Metode Penelitian Pendidikan. Jakarta: BPK Gunung Mulia.

Kartono, K. (1997). Patologi Sosial 2. Jakarta: Rajawali Pers.

Kasali, R. (2008). Membidik Pasar Indonesia: Segmentasi, Targetting, Positioning. Jakarta: Gramedia Pustaka Utama.

Napel, H. ten. (2012). Jalan Yang Lebih Utama Lagi: Etika Perjanjian Baru. Jakarta: Gunung Mulia.

Oswalt, J. N. (1986). The Book of Isaiah Chapter 1-39. Grand Rapids, Michigan: WM. B. Eerdmans Publishing Company.

Peter Garlans. (2009). Jangan Menjadi Budak Uang. Jakarta: Penerbit Guepedia.

Seapullah, A. (2020). Konsep Utilitarianisme John Stuart Mill: Relevansinya Terhadap IlmuIlmu atau Pemikiran Keislaman. Filsafat Dan Teologi Islam, 11, 243-261.

Sosipater, K. (2010). Etika Perjanjian Lama. Jakarta: Suara Harapan Bangsa. (2011). Etika Taman Eden. Jakarta: Suara Harapan Bangsa. . (2013). Etika Bisnis. Jakarta: Suara Harapan Bangsa.

Stassen, G. H., \& Gushee, D. P. (2008). Kerajaan Etika. Surabaya: Momentum.

Sukarno, N. F., \& Indrawati, E. S. (2018). Hubungan Konvormitas Teman Sebaya Dengan Gaya Hidup Hedonis Pada Siswa Di Sma Pl Don Bosko Semarang. Jurnal Empati, 7(2), 314320.

Suryanti, C. (2010). Agama Dan Iptek: Refleksi dan Tantangannya dalam Mengembangkan Moralitas Kaum Muda. Orientasi Baru, 19(2), 155-170.

Tambingon, J., Tasik, F. C. ., \& Purwanto, A. (2016). Gaya Hidup Hedonisme Mahasiswa

Fakultas Ekonomi Dan Bisnis Universitas Sam Ratulangi Di Kota Manado. Fakultas Ekonomi Dan Bisnis Universitas Samratulangi Manado, 1(043), 1-8.

Trimiarti, N. (2014). Studi Kasus Tentang Gaya Hidup Hedonisme Mahasiswa Bimbingan dan

Konseling Universitas Ahmad Dahlan. PSIKOPEDAGOGIAN, Vol.3, 20-28.

Verkuyl, J. (216AD). Etika Kristen Bagian Umum. Jakarta: BPK Gunung Mulia.

Zikrun. (2018). Teori Humanistik Abraham Maslow dalam Perpestif Islam. Skripsi, 01, 114. 